\title{
ВАРТІСТЬ МЕДИЧНОЇ ДОПОМОГИ ДІТЯМ 3 ХРОНІЧНИМИ ДЕРМАТОЗАМИ
}

Г. Б. Голяченко

\author{
Тернопільський обласний шкірвендиспансер
}

\begin{abstract}
Згідно з розробленою математичною моделлю визначена вартість лікування псоріазу та атопічного дерматиту у дітей. Захворюваність на цю патологією і вартість ії лікування постійно зростають, що обумовлює актуальність даної проблеми.
\end{abstract}

Ключові слова: хронічні дерматити у дітей, вартість медичної допомоги.

\section{СТОИМОСТЬ МЕДИЦИНСКОЙ ПОМОЩИ ДЕТЯМ С ХРОНИЧЕСКИМИ ДЕРМАТОЗАМИ}

\section{Г. Б. Голяченко}

\section{Тернопольский областной кожвендиспансер}

\begin{abstract}
Согласно разработанной математической модели определена стоимость лечения псориаза и атопического дерматита у детей. Заболеваемость этой патологией и стоимость ее лечения постоянно возрастают, что обусловливает актуальность данной темы.
\end{abstract}

Ключевые слова: хронические дерматиты у детей, стоимость медицинской помощи.

\section{COST OF MEDICAL CARE FOR CHILDREN WITH CHRONIC DERMATOSES}

\section{H. B. Holyachenko}

\section{Ternopii Regional Skin Venereal Clinic}

According to the developed mathematical model the cost of treatment of psoriasis and atopic dermatitis in children was determined. The incidence of this disease and cost of treating are increasing, which makes the urgency ofthe problem.

Key words: chronic dermatitis in children, the cost of medical care.

Вступ. Однією з гострих і невирішених проблем української охорони здоров'я на стадії ії реформування $є$ визначення іiї вартості і забезпечення економічної ефективності функціонування $[3,5,6]$. Для цього слід вирішити багато питань, початковим 3 яких $\epsilon$ вартість лікування конкретного захворювання. При цьому саме вихід на вартість лікування захворювання у конкретного лікаря $\epsilon$ основною передумовою знаходження шляхів оптимізації економічної діяльності медичного закладу [1].
Метою дослідження $є$ визначення вартості лікування хронічних дерматозів у дітей та ролі основних складових у їі формуванні,

Матеріали і методи. За приклад взято типовий випадок псоріазу та атопічного дерматиту у дітей міста Тернополя. Відбір на шпиталізацію склав $16,5 \%$.

Результати дослідження та їх обговорення. Модель обрахунку в умовах амбулаторії (поліклініки) була наступною:

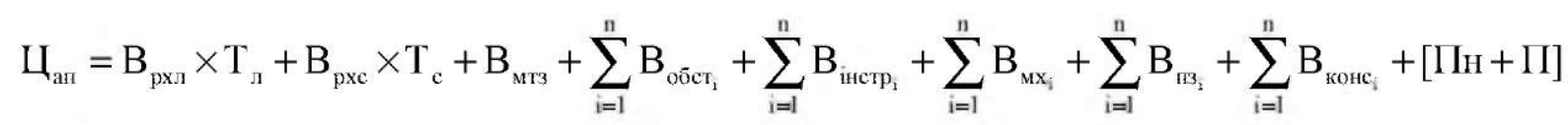

Де Ц - - ціна (вартість) допомоги, наданої амбулаторному пацієнту;

$\mathrm{B}_{\text {рхл }}$ - середня вартість робочої хвилини лікаря;

$\mathrm{T}_{я}$ - кількість хвилин, витрачених лікарем на надання допомоги пацієнту;
$\mathrm{B}_{\text {рхс }}$ - середня вартість робочої хвилини медсестри; $\mathrm{T}_{\mathrm{e}}$ - кількість хвилин, витрачених медсестрою для надання допомоги пацієнту;

$\mathrm{B}_{\text {мгз }}$ - середнє число матеріально-технічних затрат на одного амбулаторного пацієнта (відвідування). 


$$
\sum_{i=1}^{\mathrm{n}} \mathrm{B}_{\text {обет }}=\mathrm{B}_{\text {об }} \div \mathrm{T}_{\mathrm{r}} \times \mathrm{T}_{\mathrm{o}}+\mathrm{B}_{д 3}+\mathrm{B}_{\text {рхп }} \times \mathrm{T}_{\mathrm{o}}-\text { вар- }
$$

тість обстеження пацієнта

де $\mathrm{i}$ - кількість обстежень (i=1,.. .п);

$\mathrm{B}_{\text {об }} \div \mathrm{T}_{\mathrm{r}}-$ вартість (амортизація) однієї хвилини обладнання, що використане для обстеження паціснта;

' $I_{r}$ - гарантійний термін дії (у хвилинах);

$\mathrm{T}_{\text {- }}$ - термін обстеження (у хвилинах);

$\mathrm{B}_{\text {дз }}$ - вартість допоміжних засобів, що використані під час обстеження (інструментального лікування);

$\mathrm{B}_{\text {рхп }}$ - вартість робочої хвилини працівника, що проводив обстеження (інструментальне лікування);

$$
\sum_{\mathrm{i}=1}^{\mathrm{n}} \mathrm{B}_{\text {iнстр }_{\mathrm{i}}}=\mathrm{B}_{\text {ннстр }} \div \mathrm{T}_{\mathrm{r}} \times \mathrm{T}_{\text {ннстр }}+\mathrm{B}_{д 3}+\mathrm{B}_{\text {рхп }} \times \mathrm{T}_{\text {ннстр }}
$$

- вартість інструментального лікування;

де i - кількість методів інструментального лікування $(\mathrm{i}=1, \ldots$ п);

$\mathrm{B}_{\text {iнстр }} \div \mathrm{T}_{\text {, }}$

апарата, що використании для інструментального лікування;
$\mathrm{T}_{\text {iғстр }}$ - час інструментального лікування (у хвилинах);

$\sum_{\mathrm{i}=1}^{\mathrm{n}} \mathrm{B}_{\mathrm{мx}_{\mathrm{i}}}$ - вартість перев'язувальних засобів, використаних для хірургічного лікування;

де і-кількість перев'язувальнихзасобів (i=1,... .п); $\sum_{\mathrm{i}=1}^{\mathrm{n}} \mathrm{B}_{\text {конс }_{\mathrm{i}}}=\mathrm{B}_{\text {рхк }} \times \mathrm{T}_{\kappa}-$ вартість консультативної допомоги,

де i - кількість консультацій $(\mathrm{i}=1, . .$. .п);

$\mathrm{B}_{\text {рхк }}$ - вартість робочої хвилини лікаря-консультанта;

$\mathrm{T}_{\mathrm{\kappa}}$ - час консультації (у хвилинах).

Пн - прибуток

П - податок* додається при підприємницькій діяльно сті

Модель не враховує лишень постійних витрат на будівництво приміщень амбулаторно-поліклінічних закладів.

Наведемо приклад обрахунку вартості медичної допомоги в амбулаторно-поліклінічних умовах.

1. Назва захворювання:

псоріаз

2. Число відвідувань 3 приводу цього захворювання: 10

3. Кількість хвилин, витрачених лікарем на надання допомоги пацієнту (експертна оцінка, хронометраж, підкр.): $\quad \underline{15 \mathrm{xB}}$

4. Пересічна вартість робочої хвилини лікаря (сумарна зарплата за рік/59200) роб. хв на рік

$$
\underline{40,5 \text { грн }}
$$

5. Кількість хвилин, витрачених середнім медпрацівником на надання допомоги пацієнту (експертна оцінка, хронометраж підкр.) $2 \mathrm{xB}$

6. Пересічна вартість робочої хвилини середнього медпрацівника (сумарна зарплата за рік/59200) роб. хв на рік 4.2 грн.

7. Пересічне число матеріально-технічних затрат на одне амбулаторне відвідування (загальне число матеріально-технічних затрат поліклініки/число відвідувань за рік) $2,29 \times 10=22,9 г \mathrm{pH}$

8.1. Назва апарата, використаного для обстеження, лікування

Стат факс 1904

8.2. Вартість цього апарата) 27000 грн

8.3. Гарантійний термін дії апарата__ 7 років

8.4. Термін обстеження, лікування__ 115,5 хв

8.5. Вартість допоміжних засобів__ 16,61 грн

8.6. Вартість робочої хвилини працівника, який проводив обстеження, лікування

9.1. Назва апарата, використаного для обстеження, лікування, реабілітації мікроскоп «Гранул» 120

9.2. Вартість цього апарата 1800 грн

9.3. Гарантійний термін дії апарата (хв.)__ 5 років

9.4. Час обстеження, лікування, реабілітації хв.__ 17 хв 
9.5. Вартість допоміжних засобів (грн.) $\underline{0,3}$

9.6. Вартість робочої хвилини працівника, що проводив обстеження, лікування, реабілітацію (грн.)

10.1. Назва апарата, використаного для обстеження, лікування мікроскоп «Гранул» 120

10.2. Вартість цього апарата ( $\mathrm{rpnj}$

10.3. Гарантійний термін дії апарата $\underline{18000}$

10. 4. Термін обстеження, лікування, реабілітації

10. 5. Вартість допоміжних засобів__ 0,9 грн $10 \mathrm{XB}$

10. 6. Вартість робочої хвилини працівника, що проводив обстеження, лікування, реабілітацію (грн.)

11. Медикаментозні засоби; таб. Седавіт №20 15.52 грн. таб. Есенціале №30 92,80 грн. крап. Віт А 4.80 грн. таб. Нікот. к-ти №50 3.26 грн. Мезим-форте №20

грн.

12. Медикаментозні засоби для зовнішнього лікування кр. Псорікап шамп. Фрідерм з дьогтем 65.60 грн. мазь Алоком C_ 71.79 грн.

12. Лікарі-консультанти: назва, час консультації, вартість однієї робочої хвилини ліка$I^{*}$.

15. Дата заповнення

16. Хто заповнював

Разом: 40,5+4,2+22,9+42,02+3,87+3,0+283,71=400,2 грн.

Економіко-математична модель визначення вартості лікування в умовах стаціонару була такою:

$$
\begin{aligned}
\bigsqcup_{\text {сп }}= & \mathrm{B}_{\text {зплдл }} \times \mathrm{T}_{\text {лд }}+\mathrm{B}_{\text {зплдс }} \times \mathrm{T}_{\text {лд }}+\mathrm{B}_{\text {зплдм }} \times \mathrm{T}_{\text {лд }}+\mathrm{B}_{\text {мтзлд }} \times \mathrm{T}_{\text {лд }}+\mathrm{B}_{\text {хлд }} \times \mathrm{T}_{\text {лд }}+ \\
& +\sum_{\mathrm{i}=1}^{\mathrm{n}} \mathrm{B}_{\text {обст }}+\sum_{\mathrm{i}=1}^{\mathrm{n}} \mathrm{B}_{\mathrm{M}_{\mathrm{i}}}+\sum_{\mathrm{i}=1}^{\mathrm{n}} \mathrm{B}_{\text {інстр }}+\sum_{\mathrm{i}=1}^{\mathrm{n}} \mathrm{B}_{\mathrm{мx}_{\mathrm{i}}}+\sum_{\mathrm{i}=1}^{\mathrm{n}} \mathrm{B}_{\text {пз }}+\sum_{\mathrm{i}=1}^{\mathrm{n}} \mathrm{B}_{\text {конс }_{\mathrm{i}}}+\left[\Pi_{\mathrm{H}}+\Pi\right],
\end{aligned}
$$

де Ц - ціна (вартість) лікування стаціонарного пацієнта;

$\mathrm{B}_{\text {згтр }}$ - пересічна заробітна плата лікаря із розрахунку на 1 ліжко-день;

$\mathrm{B}_{\text {здлдс }}$ - пересічна сумарна заробітна плата медичних сестер із розрахунку на 1 ліжко-день;

$\mathrm{B}_{\text {зналм }}$-пересічна сумарна заробітна плата молодших медпрацівників із розрахунку на 1 ліжко-день;

$\mathrm{B}_{\text {мтзлд }}$ - вартість матеріально-технічних затрат на один ліжко-день;

$\mathrm{B}_{\text {хлд }}$ - вартість харчування хворого за день;

$\mathrm{T}_{\text {лд }}$ - число ліжко-днів; $\sum_{\mathrm{i}=1}^{\mathrm{n}} \mathrm{B}_{\mathrm{s}_{\mathrm{i}}}$ - витрати на медикаменти;

де $\mathrm{i}$ - кількість медикаментів $(\mathrm{i}=1, \ldots$.п);

$\sum_{\mathrm{i}=1}^{\mathrm{n}} \mathrm{B}_{\text {обост }}=\mathrm{B}_{\text {обо }} \div \mathrm{T}_{\mathrm{r}} \times \mathrm{T}_{\mathrm{o}}+\mathrm{B}_{д з}+\mathrm{B}_{\mathrm{px \Pi}} \times \mathrm{T}_{\mathrm{o}}$

вартість допоміжних обстежень; де i - кількість обстежень (i=1,... .п);

$\sum_{\mathrm{i}=1}^{\mathrm{n}} \mathrm{B}_{\text {інетр }}=\mathrm{B}_{\text {інетр }} \div \mathrm{T}_{\mathrm{r}} \times \mathrm{T}_{\text {інетр }}+\mathrm{B}_{\text {дз }}+\mathrm{B}_{\text {рхп }} \times \mathrm{T}_{\text {інетр }}$

- вартість інструментальних методів лікування, включно з хірургічними; 
де і - кількість методів інструментального лікування $(\mathrm{i}=1, \ldots \Pi)$;

$$
\sum_{\mathrm{i}=1}^{\mathrm{n}} \mathrm{B}_{\mathrm{Mx}} \text { - вартість медикаментів, що використані }
$$

під час хірургічного втручання, інструментального лікування;

де i-кількість медикаментозних засобів $(\mathrm{i}=1, \ldots . \Pi)$; $\sum_{i=1}^{n} T_{n_{i}}$ вартість перев'язувальних засобів, що використані під час хірургічних втручань і лікування; де i - кількість перев'язочних засобів (i=1,...n); $\sum_{\mathrm{i}=1}^{\mathrm{n}} \mathrm{B}_{\text {конс }}=\mathrm{B}_{\text {рхк }} \times \mathrm{T}_{\kappa}-$ вартість консультативної допомоги

де i - кількість консультацій $(\mathrm{i}=1, \ldots$.п);

$\mathrm{B}_{\text {рхк }}$ - вартість робочої хвилини консультанта (допоміжного працівника);

$\mathrm{T}_{\mathrm{K}}$ - час консультацій (допоміжні роботи, хв).

Модель не враховує лише постійних витрат на будівництво стаціонару.

Приклад обрахунку вартості лікування в стаціонарних умовах наведено нижче:

1. Назва захворювання атопічний дерматит

2. Число ліжко-днів 3 приводу цього захворювання 12

3. Пересічна заробітна плата лікаря із розрахунку на один ліжко-день $\underline{2,38 \times 12=28,56 \text { грн }}$

4. Пересічна заробітна плата медичної сестри із розрахунку на один ліжко-день $\underline{1.84 \times 12=22.08 \text { ПPH }}$

5. Пересічна заробітна плата молодшої медичної сестри із розрахунку на один ліжко-день $\underline{1.38 \times 12=16.56 \text { грн }}$

6. Пересічне число матеріально-технічних затрат на один ліжко-день (загальне число матеріально-технічних затрат стаціонару/число ліжко-днів) $14.99 \times 12=179.88$ грн

7. Вартість харчування хворого за день $7.80 \times 12=93.6$ грн

8.0

8.1. Назва апарата, використаного для обстеження, лікування, реабілітації мікроскоп «Гранул» 120

8.2. Вартість цього апарата грн.) 18000 грн

8.3. Гарантійний термін дії апарата__ 5 років

8.4. Термін обстеження, лікування_ $17 \mathrm{xB}$

8.5. Вартість допоміжних засобів (грн.) $\quad 0,3$ грн

6. Вартість робочої хвилини працівника, що проводив обстеження, лікування $\underline{0.21 \times 17=3.57 \Gamma \mathrm{pH}}$

9.0

9.1. Назва апарата, використаного для обстеження, лікування, реабілітації Статфакс 1904

9.2. Вартість цього апарата 27000 грн

9.3. Гарантійний термін дії апарата__ 7 років

9.4. Час обстеження, лікування, реабілітації 115,5 хв

9.5. Вартість допоміжних засобів 16,61 грн

9.6. Вартість робочої хвилини працівника, що проводив обстеження, лікування, реабілітацію (грн.)

10.0

1. Назва апарата, використаного для обстеження, лікування, реабілітації

2. Вартість цього апарата (грн.)

3. Гарантійний термін дії апарата (хв.)

4. Термін обстеження, лікування, реабілітації (хв.)

5. Вартість допоміжних засобів (грн.)

6. Вартість робочої хвилини працівника, що проводив обстеження, лікування, реабілітацію (грн.) 
11. Медикаментозні засоби: p-н Дексаметазон амп.

6,56 грн.

\begin{tabular}{ll}
\hline Фізіол. р-н & 13,92 грн. \\
\hline Реосорбілакт & 84,40 грн. \\
\hline таб. Кетотіфен & 5,44 грн. \\
\hline Лоратадин & 5,40 грн. \\
\hline Преднізолонова мазь & 14,18 грн. \\
\hline мазь "Бетаметазон" & 13,75 грн. \\
\hline таб. "Персен" & 36,20 грн. \\
\hline мазь "Локоід" & 42,00 грн. \\
\hline крем "Декубель" & 64,38 грн. \\
\hline
\end{tabular}

12. Перев'язувальні засоби: грн.

13. Лікарі-консультанти: назва, час консультації, вартість однієї робочої хвилини лікаря

\section{4. Дата заповнення}

15. Хто заповнював

Разом: $28,56+22,08+16,56+179,80+93,6+3,87+42,02+286,23=672,8$ грн.

Вартість завжди конкретна. Досить сказати, що протягом останніх 20 років захворюваність у нас зростала на 3-4 \% в рік. В даному випадку ми рахуємо вартість медичної допомоги в 2010 р.

Модель дозволяє обрахувати вартість за умов дотримання стандарту, або т.з. нормативну вартість, i фактичну. Порівняння двох вартостей з виходом на конкретне захворювання і конкретного лікаря дає багато керівнику для прийняття управлінських рішень.

На вартість впливає організаційна структура медичної допомоги. Одна справа, коли сімейний лікар надає 90 \% допомоги і інша, коли 20 \%. Не треба чекати, коли сімейний лікар наростить обсяг допомоги, ми в змозі порахувати вартість за різних умов організації мед. допомоги.

Вартість залежить від технічного оснащення лікаря, яке має тенденцію до неухильного зростання;

\section{Література}

1. Голяченко О. М. Економіка української здоровоохорони//О. М. Голяченко, А. О. Голяченко.-Вінниця.: Віноблдрукарня, 1996. - 100 с.

2. Лунская Л. Л. К вопросу о методических принципах расчетов стоимости медицинских услуг // Л. Л. Лунская Экономика здравоохранения. - 2001.- № 1. - С. 30-31. 3. Кризина Н. П. Обгрунтування реформування галузі охорони здоров'я за даними України та зарубіжних країн у контексті політики Всесвітньої організації охорони здо- тут маємо виходити із реальних цифр, які були в 2010 р. Відомо, що вітчизняна медична допомога лікує довше, порівняно зі світовими стандартами, тобто кожне захворювання потребує певної кількості амбулаторних відвідувань і днів перебування на ліжку. Тут також виходимо із наших реальних цифр.

Висновки. 1. Вартість лікування псоріазу в амбулаторно-поліклінічних умовах на 2010 склала 400,2 грн., атопічного дерматиту в умовах стаціонару - 672,8 грн. Ця вартість постійно зростає.

2. В структурі витрат на амбулаторно поліклінічне лікування провідне місце обіймало медикаментозне лікування та обстеження, в умовах стаціонару - матеріально-технічні витрати і медикаментозне лікування. В обох випадках затрати на оплату праці медичних працівників були незначні.

ров'я / Н.П. Кризина // Україна. Здоров'я нації. - 2008. № 1 . - С. $80-86$.

4. Реформування вторинної медичної допомоги в Україні: базова проблематика та варіанти вирішення. Зведений звіт. $-2007 .-78 \mathrm{c}$.

5. Скороход А. В. Шляхи реформування системи фінансування охорони здоров'я в Україні / А. В. Скороход // Вісник соціальної гігієни та організації охорони здоров'я України. - 2010. - № 4. - С. 31-34. 
6. Указ Президента України від 06.12.2005 № 1694/2005 «Про невідкладні заходи щодо реформування системи охорони здоров'я населення».

7. Шевченко М. В. Аналіз окремих нормативно-правових актів з питань основної діяльності охорони здоров'я та можливого впливу на проведення реформування системи охорони здоров'я України / М. В. Шевченко // Главный врач. - 2010. - № 12. - С. 20-26.

8. Шевченко О. М. Наукове обгрунтування ціноутворення медичної допомоги на прикладі хвороб системи кровообігу : автореф. дис. канд. мед. наук: 14.02.03. / О. М. Шевченко - К., 2005. - 20 с.
9. Improving Intergovernmental Fiscal Relations and Public Health and Education Expenditure Policy: Selected Issues Report No. 42450- UA Ukraine, November 20, 2007

10. Hospital Reconfiguration: an ippr briefing, Institute for Public Policy Research, UK, Sept 2006.

11. Cost and cost effectiveness et 1 year in the Stent or Surgery trial $(\mathrm{SoS}) /$ W. Weintraub, E. Mahoney, Z. Zhang [et al.] // Eur. Heart J. - 2002. - Vol. 23 (Suppl.). - P. 137. 